\title{
Reviewing sports sciences students' perceived freedom levels in leisure in terms of any variables (Kocaeli university case)
}

\author{
Hakan Akdeniz ${ }^{1}$ Yeşim Körmükçü ${ }^{1, *}$ Gülşah Sekban ${ }^{2}$ and İrem Bostan ${ }^{1}$ \\ ${ }^{1}$ Kocaeli University Sports Sciences Faculty Recreation Department \\ ${ }^{2}$ Kocaeli University Sports Sciences Faculty Physical Education and Sports Teaching Department
}

\begin{abstract}
This study was executed with the aim of investigating whether the perceived freedom levels of students who study in the Faculty of Physical Education and Sports Sciences vary by any variables. The target population of the study composed of 240 voluntary students who study at Kocaeli University, the Faculty of Physical Education and Sports Sciences, $132(55 \%)$ of whom was female and 108 (45\%) of whom were male. Perceived Freedom in Leisure Scale, which was developed by Witt and Ellis (1985) and adopted into Turkish by [21] was used as the data collection tool of the study. Kolmogrov-Smirnof test analyzed whether the data showed normal distribution and it was observed that data do not display a normal distribution. As a result of this, Mann Whitney $U$ and Kruskal Wallis $\mathrm{H}$ tests were applied. The significance level was considered as 0,05 . No significant difference was identified between perceived freedom levels in leisure by means of certain variables such as gender, department, participation in social activities, approximate participation in recreation activities and frequency of leisure participation $(\mathrm{p}>0,05)$. A significant difference was found between knowledge and skill - excitement and joy by means of participation in sportive activities, participation in cultural and artistic activities and competence in recreation areas $(p<0,05)$. Consequently, when knowledge and skill - excitement and joy sub-dimensions of students who use their recreational areas, attend to sportive and artistic activities were evaluated, it was seen that individuals who actively participate in any activity may perceive him or herself freer when he or she is compared to the individuals who participate in an activity in a passive way. Therefore, a further activity participation sense may be created.
\end{abstract}

\section{INTRODUCTION}

People in modern societies need activities in leisure time besides to blow off steam beside relaxation. Leisure time is the time that person gets rid of all challenges or connections and makes an activity that he desires [2].. Moreover, leisure time is the period that is left from the things that the person is obliged to make to meet the needs (eating, sleeping, physical needs) and sustain the life $[10,19]$. In the light of all these expressions, the leisure time is

* Corresponding author: ysmkormukcu@gmail.com 
accepted as the time period that has satisfactory experiences, free of charge, exciting the sense of happiness and gladness. Personal control is provided independently from the external pressures $[9,13,14]$. mentioned that the activities that people attend to value this period are the recreative activities or leisure time activities which individuals participate in to value this period. Even though the leisure time activities or recreative activities concepts mean valuing the leisure times, they also mean restful and funny activities that individual voluntarily participate in to enjoy or develop physical, social and affective behaviors $[5,6]$. People want to value the leisure time by actively or passively participating in leisure time activities in open and confined spaces in urban and rural areas because of several different reason and expectations [5].

There are various dimension and reasons for people to prefer and participate in the recreative activities. Desiring a repetition of an activity after performing it is the conclusion of positive experiences and perceiving that activity process as positive. Participating in the recreative activities is important because of creating freedom perception [1].

There are several studies show that active participation constitutes positive emotions on the individuals $[3,12,24]$. The freedom concept that is perceived as one of those feelings has emerged as a significant dimension to measure the leisure time behavior. It is assumed that the perceived freedom concept provides a causative relationship between the actor and the behavior as well as underlies the behavior of the actor himself [4].

Optimal effects of participating in the leisure time activities are associated with the freedom perception and controlling the leisure time optionally. Perceived freedom is a significant dimension to understand the leisure time activities. According to Heider's definition, perceived freedom is a tool that is used to estimate the human behaviors. It is the expression of the sense of perceived freedom of a person against the acts of another person. Besides, the perceived freedom is closely related to the responsibility and intent [1].

Since perceiving the freedom in leisure time is a voluntary behavior [17] and the individuals need to have skills such as competence, controlling the experiences and participating in the activities by internal expectations[20], perceiving the freedom is a concept that is needed for attention in measuring the leisure time behavior.

The main focus of the freedom concept that is perceived in leisure time is based on Neulinger's theory (1974) called 'leisure time as a mood' [22]. Perceived freedom is expressed as a cognitive-motivational structure by [20]. It is pointed out within this scope that one of the components that leisure time behavior depends is the depth of the participation.

This research aimed to review the perceived freedom based on gender, department, participation to social, sportive, cultural and artistic activities, leisure time and recreation area adequacy variables in terms of measuring the behaviors of students towards the leisure time activities.

\section{Methodology}

\subsection{Research Group}

The population was composed of 967 students of Sports Sciences Faculty in Kocaeli University. Those students chose one of the lessons from among basketball, football, volleyball, mountaineering, handball, fitness, swimming, chess, tennis, and table-tennis in the 2016-2017 academic year. This randomized sample group consisted of 240 students whose $132(55 \%)$ of them were male and $108(45 \%)$ of them were females. 


\subsection{Data Collection Tools:}

In the first stage, the personal information form that has 10 questions on age, gender, university and department, leisure time, type of leisure time activities was used. In the second stage 'Perceived Freedom Leisure Scale' that was developed by [20] to measure the competencies, perceived control and perceived internal motivation was used. This same scale was adapted to Turkish by [26]; they also performed reliability and validity works of the scale. The original form of the scale is composed of 25 items; however, there was reached 17 items at the end of the factor analysis conducted. The scale consists of 2 subdimensions as (1) Knowledge and skill, (2) Excitement and Entertainment. Internal consistency coefficient of the scale was found as .94 as the result of the reliability and validity studies of [26]. Internal consistency coefficient was computed as .85 for knowledge and skill sub-dimension; .83 for excitement and entertainment sub-dimension. The scale mentioned is a five-point Likert scale; the questions are answered as 1 "Strongly Disagree", 5 "Strongly Agree" [26]. Knowledge and skill sub-dimension has 1st, 2nd, 3rd, 4th, 5th, 8th, 9th, 10th, 15th; excitement and entertainment sub-dimension has 6th, 7th, 11th, 12th, $13 \mathrm{rd}, 14 \mathrm{th}, 16 \mathrm{th}, 17 \mathrm{th}$.

\subsection{Data Collection}

Data collection process for students of Sports Sciences Faculty of Kocaeli University was actualized in the spring terms of the 2016-2017 academic year. Students were informed about the qualification before the data collection; it was also provided to be counted the volunteer participants in the research. It was asked them to deliver the surveys within the same day to avoid the data loss in survey collecting. Missing answered questionnaires were not included in the study.

\subsection{Data Analysis}

Data were organized in Microsoft Excel 2013 program and analyzed by using SPSS 21.0 packaged software. Percentage and frequency methods were used to determine the distribution of the personal information of participants. Kolmogrov-Smirnof test was applied to specify whether the sub-dimensions of both scales show a normal distribution. With reference to the test results, all the sub-dimension of Perceived Freedom in Leisure Scale do not show normal distribution. Mann Whitney U test was utilized for bivariant data; Kruskal Wallis test was applied for more than two variables. The significance level was accepted as $\mathrm{p}<, 05$. 


\section{Findings}

Table1. Gender distribution of participants

\begin{tabular}{ccc}
\hline Gender & $\mathbf{n}$ & $\mathbf{\%}$ \\
\hline Male & 132 & 55,0 \\
Female & 108 & 45,0 \\
\hline
\end{tabular}

Table2. Department distribution of participants

\begin{tabular}{ccc}
\hline Department & n & $\mathbf{\%}$ \\
\hline Coaching & 48 & 20,0 \\
Physical Education and Sports & 46 & 19,2 \\
Teaching & 97 & 40,4 \\
Recreation & 49 & 20,4 \\
Sports Management & 240 & 100,0 \\
Total &
\end{tabular}

Table 3. Weekly leisure time of participants

\begin{tabular}{ccc}
\hline Weekly Leisure Time & $\mathbf{n}$ & $\mathbf{\%}$ \\
\hline $1-5$ hours & 27 & 11,2 \\
$6-10$ hours & 78 & 32,5 \\
$11-15$ hours & 64 & 26,7 \\
16 hours and above & 71 & 29,6 \\
Total & 240 & 100,0 \\
\hline
\end{tabular}

Table 4. Types of participating in sportive activities as leisure time activity distribution of participants

\begin{tabular}{cccc}
\hline Activity & Type of Participation & n & \% \\
\hline \multirow{2}{*}{ Sportive Activity } & Aktive & 208 & 86,7 \\
& Pasive & 32 & 13,3 \\
Total & & 240 & 100,0 \\
\hline
\end{tabular}

Table 5. Types of participating in sportive activities as leisure time activity distribution of participants

\begin{tabular}{cccc}
\hline Activity & Type of Participation & n & \% \\
\hline \multirow{2}{*}{ Social Activity } & Active & 186 & 77,5 \\
Total & Passive & 54 & 22,5 \\
& & 240 & 100,0 \\
\hline
\end{tabular}

Table 6. Types of participating in cultural and artistic activities as leisure time activity distribution of participants

\begin{tabular}{cccc}
\hline Activity & Type of Participation & n & \% \\
\hline Cultural and Artistic & Active & 69 & 28,7 \\
Activity & Passive & 171 & 71,3 \\
Total & & 240 & 100,0 \\
\hline
\end{tabular}

Table 7. Recreative area adequacy of university to participants' mind

\begin{tabular}{ccc}
\hline Recreative Area & $\mathbf{n}$ & $\mathbf{\%}$ \\
\hline Absolutely Adequate & 10 & 4,2 \\
Adequate & 90 & 37,5 \\
Partly & 84 & 35,0 \\
Inadequate & 43 & 17,9 \\
Absolutely Inadequate & 13 & 5,4 \\
Total & 240 & 100,0 \\
\hline
\end{tabular}


Table 8. Relationship of perceived freedom in leisure sub-dimension based on gender variable

\begin{tabular}{cccccc}
\hline & Gender & $\mathbf{N}$ & $\begin{array}{c}\text { Rank Value } \\
\text { Average }\end{array}$ & $\mathbf{z}$ & $\mathbf{p}$ \\
\hline $\begin{array}{c}\text { Knowledge and Skill sub- } \\
\text { dimension }\end{array}$ & Male & 132 & 121,98 &,- 368 &, 713 \\
$\begin{array}{c}\text { Excitement and } \\
\text { Entertainment sub- } \\
\text { dimension }\end{array}$ & Female & 108 & 118,69 & & \\
\hline
\end{tabular}

Table 9. Relationship of perceived freedom in leisure sub-dimension based on department

\begin{tabular}{|c|c|c|c|c|c|}
\hline & Department & $\mathbf{n}$ & $\begin{array}{c}\text { Rank Value } \\
\text { Average }\end{array}$ & df & $\mathbf{p}$ \\
\hline \multirow{7}{*}{$\begin{array}{l}\text { Knowledge and } \\
\text { Skill sub- } \\
\text { dimension }\end{array}$} & Coaching & 48 & 120,79 & \multirow{7}{*}{3} & \multirow{7}{*}{,950 } \\
\hline & Physical & 46 & 125,65 & & \\
\hline & Education and & & & & \\
\hline & Sports Teaching & & & & \\
\hline & Recreation & 97 & 118,59 & & \\
\hline & Sports & 49 & 119,16 & & \\
\hline & Management & & & & \\
\hline \multirow{7}{*}{$\begin{array}{l}\text { Excitement and } \\
\text { Entertainment sub- } \\
\text { dimension }\end{array}$} & Coaching & 48 & 133,22 & \multirow{7}{*}{3} & \multirow{7}{*}{,370 } \\
\hline & Physical & 46 & 118,13 & & \\
\hline & Education and & & & & \\
\hline & Sports Teaching & 07 & 11285 & & \\
\hline & Sports & 49 & 125,42 & & \\
\hline & Management & & & & \\
\hline & Total & 240 & & & \\
\hline
\end{tabular}

Table 10. Relationship of perceived freedom in leisure sub-dimension based on leisure time period variable

\begin{tabular}{|c|c|c|c|c|c|}
\hline & Leisure Time Period & $\mathbf{n}$ & $\begin{array}{c}\text { Rank Value } \\
\text { Average }\end{array}$ & df & $\mathbf{p}$ \\
\hline \multirow{5}{*}{$\begin{array}{l}\text { Knowledge and Skill } \\
\text { sub-dimension }\end{array}$} & $1-5$ hours & 26 & 136,19 & \multirow{5}{*}{3} & \multirow{5}{*}{,474 } \\
\hline & 6-10 hours & 78 & 123,85 & & \\
\hline & $11-15$ hours & 64 & 114,24 & & \\
\hline & 16 hours and above & 71 & 115,03 & & \\
\hline & Total & 239 & & & \\
\hline \multirow{5}{*}{$\begin{array}{l}\text { Excitement and } \\
\text { Entertainment sub- } \\
\text { dimension }\end{array}$} & $1-5$ hours & 26 & 131,15 & \multirow{5}{*}{3} & \multirow{5}{*}{,605 } \\
\hline & $6-10$ hours & 78 & 123,09 & & \\
\hline & 11-15 hours & 64 & 120,70 & & \\
\hline & 16 hours and above & 71 & 111,89 & & \\
\hline & Total & 239 & & & \\
\hline
\end{tabular}

Table 11. Relationship of perceived freedom in leisure sub-dimension based on participating in social activities variable

\begin{tabular}{ccccccc}
\hline & $\begin{array}{c}\text { Participating in } \\
\text { social activities }\end{array}$ & $\mathbf{n}$ & $\begin{array}{c}\text { Rank value } \\
\text { average }\end{array}$ & Average & $\mathbf{z}$ & $\mathbf{p}$ \\
\hline Knowledge and & Active & 186 & 120,12 & 22343,00 & & \\
Skill sub- & Passive & 54 & 121,80 & 6577,00 &,- 157 &, 875 \\
dimension & Total & 240 & & & & \\
Excitement and & Active & 186 & 124,88 & 23228,00 & &, 067 \\
Skill sub- & Passive & 54 & 105,41 & 5692,00 & $-1,830$ & \\
dimension & Total & 240 & & & & \\
\hline
\end{tabular}


Table 12. Relationship of perceived freedom in leisure sub-dimension based on participating in cultural and artistic activities variable

\begin{tabular}{ccccccc}
\hline & $\begin{array}{c}\text { Participating in } \\
\text { Cultural and } \\
\text { Artistic Activities }\end{array}$ & $\mathbf{n}$ & $\begin{array}{c}\text { Rank } \\
\text { Value } \\
\text { Average }\end{array}$ & Average & $\mathbf{z}$ & $\mathbf{p}$ \\
\hline Knowledge and & Active & 68 & 140,38 & 9546,00 & & \\
Skill sub- & Passive & 172 & 112,64 & 19374,00 & $-2,813$ &, 005 \\
dimension & Total & 240 & & & & \\
Excitement and & Active & 68 & 138,11 & 9391,00 & & \\
Entertainment & Passive & 172 & 113,54 & 19528,00 & $-2,485$ &, 013 \\
sub-dimension & Total & 240 & & & & \\
\hline
\end{tabular}

Table 13. Relationship of Perceived Freedom in Leisure Sub-Dimension Based on Participating in Sportive Activities Variable

\begin{tabular}{ccccccc}
\hline & $\begin{array}{c}\text { Participating in } \\
\text { Sportive Activities }\end{array}$ & $\mathbf{n}$ & $\begin{array}{c}\text { Sira Değer } \\
\text { Ortalama }\end{array}$ & Ortalama & $\mathbf{z}$ & p \\
\hline Information and & Active & 208 & 128,57 & 26742,00 & $-4,615$ &, 000 \\
Skill sub-dimension & Passive & 32 & 68,06 & 2178,00 & & \\
Excitement and & Active & 208 & 125,56 & 26115,50 & & \\
Entertainment sub- & Passive & 32 & 87,64 & 2804,50 & $-2,900$ &, 004 \\
$\quad$ dimension & Total & 240 & & & & \\
\hline
\end{tabular}

Table 14. Relationship of perceived freedom in leisure sub-dimension based on recreational areas adequacy variable

\begin{tabular}{lccccc}
\hline & $\begin{array}{l}\text { Recreational Areas } \\
\text { Adequacy }\end{array}$ & n & $\begin{array}{c}\text { Rank Value } \\
\text { Average }\end{array}$ & df & p \\
\hline Absolutely Adequate & 10 & 120,05 & & \\
Anformation and Skill & Adequate & 90 & 132,94 & & \\
sub-dimension & Partly & 84 & 100,67 & 4 &, 026 \\
& Anadequate & 43 & 131,43 & & \\
Absolutely Inadequate & 13 & 126,65 & & \\
Excitement and & Total & 240 & & & \\
Entertainment sub- & Absolutely Adequate & 10 & 89,60 & & \\
dimension & Adequate & 90 & 119,69 & & \\
& Partly & 84 & 106,31 & 4 & \\
& Inadequate & 43 & 145,57 & & \\
\hline
\end{tabular}

There was a significant relationship $(\mathrm{p}<0,05)$ between sub-dimensions perceived in leisure time and participating in cultural, artistic, sportive activities and recreation areas variables

\section{Discussions}

This research aimed to review the perceived freedom of students study in Sports Sciences Faculty of Kocaeli University based on gender, department, participation to social, sportive, cultural and artistic activities, leisure time and recreation area adequacy variables in terms of measuring the behaviors of students towards the leisure time activities.

There was not found a significant difference between the sample group's perceived freedom levels based on gender, department, participation in social activities and leisure time. However, significant differences were observed between recreational area adequacy and participation to sportive, cultural and artistic activities. 
According to another finding, there was no significant difference in 'Knowledge and Skill' (,713) and 'Excitement and Entertainment' (,851) sub-dimensions based on gender variable. Lapa and Ağyar [23] conducted a study to determine the perceived freedom levels of university students based on leisure time participation. They pointed out that the gender is not a significant factor in specifying the perceived freedom level. [27]; performed a survey towards the perceived freedom in leisure time and leisure time satisfaction levels of the employees work in catering food-drink sector. With reference to their research findings, there are significant differences in 'Knowledge and Skill' sub-dimension. It can be seen when viewed from this aspect that our research finding shows parallelism with their research in terms of 'Knowledge and Skill' sub-dimension.

There was not found a significant difference in 'Knowledge and Skill' (,950) and 'Excitement and Entertainment' $(, 370)$ sub-dimensions in terms of the perceived freedom levels based on the department. According to this outcome, even though the students study in different departments, they approach to the leisure time activities by the similar attitudes. While the students of Recreation department get excited more in comparison with the students study in Physical Education and Sports Teaching, the participants sho study in Coaching and Sports Management department accept themselves as well-versed on this activity.

There was not found a significant difference in 'Knowledge and Skill' (,474) and 'Excitement and Entertainment' (,605) sub-dimensions in terms of the freedom levels perceived in leisure time.

It was observed that the participants actively participate in the sportive and social activities; they passively participate in the cultural and artistic activities. We can easily see that active participants participate to leisure time activities at a higher rate in comparison with the participants who passively attend in the same activities based on the types of participation in knowledge and skill sub-dimension. The research that was performed by [23] shows parallelism with our research findings. Moreover, our research findings have parallelism with the study that was conducted by [16] as well.

This research reviewed whether being the participation active or passive create the difference in perceived leisure times. It is seen that the perceived freedom levels of active participants are higher than the passive participants in all of the social activities. Besides, there were mostly the passive participants who attend in the cultural and artistic activities.

There was seen a significant difference in 'Knowledge and Skill' $(, 0,12)$ and 'Excitement and Entertainment' $(, 0,06)$ sub-dimensions in terms of perceived freedom levels in leisure time based on participation to the cultural and artistic activities.

[22] conducted a study and modeled the structural relationship of perceived freedom and leisure time participation; this relationship revealed a compatible model. Finding the perceived freedom is high is normal when the previous studies [3, [12], [24] on the positive feelings of the active participation to the leisure time activities on the people are considered.

There was found a significant difference in 'Knowledge and Skill' (,026) and 'Excitement and Entertainment' (,004) sub-dimensions in terms of the perceived freedom in leisure time based on the recreational area adequacy. It was observed with regard to this finding that the general run of the students finds the recreational areas as adequate. Also, the ratio of students who answered as 'partly' is close to the ratio of students who find those areas as adequate.

In some of the situations, the perceived freedom in leisure time has an improver effect on the leisure time participation. [11] performed a study for the high school students and emphasized that the leisure time participation is significantly higher in students with high freedom levels. [25] expressed that the perceived freedom in leisure time is a mechanism 
that affects the satisfaction for leisure time needs, competence, depth of the participation and leisure time outputs in children (10-13 ages) with developmental coordination disorder.

\section{References}

1. Ardahan, F. Turgut, T. Kalkan, K. (2016). Her Yönüyle Rekreasyon Ankara: Detay yayıncilik.

2. Bakır M. (1990). Rekreasyon ve Turizm İlişkisinin Turizm Politikalarının Oluşturulmasındaki Önemi. Basılmamış Doktora Tezi. İstanbul Üniversitesi. Sosyal Bilimler Enstitüsü.

3. Caldwell L, Smith E, Weissenger E. (1992). The relationship of leisure activities and perceived health of college students. Society and Leisure, 15(2), 545-556.

4. Kane TR, Joseph JM, Tedeschi JT. (1977). Perceived freedom, aggression and responsibility, and the assignment of punishment. The Journal of Social Psychology, 103, 257-263.

5. Karaküçük S. (2005). Rekreasyon. Ankara: Gazi Kitabevi.

6. Kılbaş Ş. (2001). Rekreasyon: Boş Zamanı Değerlendirme. Adana: Anaca Yayınları.

7. Lapa TY, Ağyar E. (2011). Cross-cultural adaptation of perceived freedom in leisure scale. World Applied Sciences Journal, 14(7), 980-986.

8. Lapa, T. Y., Ağyar, E. (2012). Üniversite Öğrencilerinin Serbest Zaman Katılımlarına Göre Alg1lanan Özgürlük. Spor Bilimleri Dergisi, 23(1), 24-33.

9. Mieczkowski Z. (1990). World Trend in Tourism and Recreation. New York: Peter Lang Publishing

10. Mull RF, Bayless KG, Ross CM, Jamieson LM. (1997). Recreational Sport Management. (3th Edition) USA: Human Kinetics.

11. Munson WW. (1993). Perceived freedom in leisure and career salience in adolescence. Journal of Leisure Research, 5(3), 305-314

12. Murphy H. (2003). Exploring leisure and psychological health and wellbeing: Some problematic issues in the case of Northern ireland. Leisure Studies, 22(1), 37-50.

13. Önder S. (2003). Selçuk üniversitesi öğrencilerinin rekreasyonel eğilim ve taleplerinin belirlenmesi üzerine bir araştırma. S. Ü. Ziraat Fakültesi Dergisi, 17(32), 31-38.

14. Ragheb MG, Tate RL. (1993). A behavioral model of leisure participation based on leisure attitude, motivation and satisfaction. Leisure Studies, 12, 61-70.

15. Serdar E. Ay SM. (2016) Üniversite Öğrencilerinin Katıldıkları Serbest Zaman Etkinliklerinden Tatmin Olma ve Algılanan Özgürlük Düzeylerinin İncelenmesi. Sobider Sosyal Bilimleri Dergisi. 3(9), 365-374

16. Serdar E. (2016). Üniversite Öğrencilerinin Katıldıkları Serbest Zaman Etkinliklerinden Tatmin Olma ve Algılanan Özgürlük Düzeylerinin İncelenmesi. Yayınlanmış Yüksek Lisans Tezi, Marmara Üniversitesi. Sağlık Bilimleri Enstitüsü.

17. Siegenthaler KL, O'Dell I. (2000). Leisure attitude, leisure satisfaction and perceived freedom in leisure within family dyads. Leisure Sciences, 22, 281-296.

18. Şener A. (2009). Yaşlılık, yaşam doyumu ve boş zaman faaliyetleri. Çağın Polisi Dergisi. 93, 04 Nisan 2012, http://www.sdergi.hacettepe.edu.tr/yasamdoyumu.pdf.

19. Torkildsen G. (2005). Recreation and Leisure Management (5th Edition). London and New York: Routledge, Taylor and Francis Group.

20. Witt PA, Ellis GD. (1985). Development of a short form to assess perceived freedom in leisure. Journal of Leisure Research, 17(3), 225-233.

21. Yerlisu Lapa, T., \& Agyar, E. (2011). Cross-cultural adaptation of perceived freedom in leisure scale. World Applied Sciences Journal, 14(7), 980-986.

22. Wu HC, Liu A, Wang CH. (2010). Taiwanese university students' perceived freedom and participation in leisure. Annals of Leisure Research, 13(4), 679-700. 
23. Yerlisu Lapa, T., Ağyar, E., \& Bahadır, Z. (2012). Yaşam tatmini, serbest zaman motivasyonu, serbest zaman katılımı: beden eğitimi ve spor öğretmenleri üzerine bir inceleme (Kayseri ili örneği). Spormetre Beden Ĕ̆itimi ve Spor Bilimleri Dergisi, X (2), 53-59.

24. Şener A. (2009). Yaşlılık, yaşam doyumu ve boş zaman faaliyetleri. Çağın Polisi Dergisi. 93, 04 Nisan 2012, http://www.sdergi.hacettepe.edu.tr/yasamdoyumu.pdf.

25.Poulsen AA, Ziviani JM, Cuskelly M. (2007). Perceived freedom in leisure and physical co-ordination ability: Impact on out-of-school activity participation and life satisfaction. Child: Care, Health and Development, 33(4), 432-440.

26. Yerlisu Lapa, T., \& Agyar, E. (2011). Cross-cultural adaptation of perceived freedom in leisure scale. World Applied Sciences Journal, 14(7), 980-986.

27. Kodaş, D., Kodaş B., Arıca, R. (2015) Yiyecek içecek Çalışanlarının Serbest Zaman tatmin Düzeyleri ile Serbest Zaman Algılanan Özgürlüklerinin İncelenmesi 3. Rekreasyon Araştırmaları Kongresi, Eskişehir Anadolu Üniversitesi. 